\title{
ANALISA PERFORMA HIDROLIK MEJA MAINTENANCE LARAS MERIAM 57mm S-60 ANTI AIRCRAFT \\ Jeffri Ferdani ${ }^{1}$, I Made Sunada ${ }^{2 *}$, M Ali $^{1}$ \\ ${ }^{1}$ Jurusan Teknik Otoranpur, Poltekad \\ ${ }^{2}$ Jurusan Teknik Mesin, Fakultas Teknik, Universitas Merdeka Malang \\ *Email corresonding author: imade.sunada@unmer.ac.id
}

\begin{abstract}
Abstrak
Penelitian ini bertujuan menganalisa performa sistem hidrolik meja maintenance pelepas laras Meriam $57 \mathrm{~mm}$. Performa dari sistem hidrolik ditunjukan oleh nilai tekanan kerja dan daya baik, daya pompa hidrolik maupun daya motor listrik. Hasil pengujian menunjukan performa sistem hidrolik alat meja maintenance bekerja sangat baik dan aman hal ini ditunjukan oleh kemampuan pompa 205,95 bar, daya kerja motor listrik 0,56 kW dengan efisiensi 85\%. Debit pompa hidrolik 11,524 1/menit, tekanan kerja pompa hidrolik 24,35 bar. Penggunaan alat hidrolik ini mampu menghemat waktu pelepasan laras meriam $57 \mathrm{~mm}$ AA dengan berat $330 \mathrm{~kg}$, dibanding pelepasan secara manual
\end{abstract}

Kata Kunci: Performa, Sistem Hidrolik, Meja Maintenance

\begin{abstract}
This study aims to analyze the performance of the hydraulic system maintenance 57 mm Cannon barrel release table maintenance. The performance of a hydraulic system is shown by the value of both working pressure and power, hydraulic pump power and electric motor power. The test results show the performance of the hydraulic system maintenance tool table works very well and safely this is shown by the ability of the pump 205.95 bar, the working power of $0.56 \mathrm{~kW}$ electric motor with $85 \%$ efficiency. Hydraulic pump discharge 11,524 l / min, hydraulic pump working pressure 24.35 bar. The use of this hydraulic tool is able to save time releasing $57 \mathrm{~mm}$ AA cannon barrel with a weight of $330 \mathrm{~kg}$, compared to the manual release
\end{abstract}

Keywords: Performance, Hydraulic Systems, Maintenance Tables

\section{PENDAHULUAN}

Meriam 57mm AA adalah jenis meriam buatan Uni Soviet (Rusia) yang berfungsi sebagai Alutsista pertahanan udara. Adapun kelemahan terhadap Alutsista tersebut yaitu pada saat pelaksanaan tembakan terus menerus terjadi gangguan, sehingga memerlukan pembongkaran laras dan perawatan laras. Selama ini pelaksanaan pembongkaran laras dan perawatan laras dengan berat laras meriam yang beratnya 330 $\mathrm{kg}$, harus memerlukan waktu yang lama dan banyak personil untuk mengangkat laras tersebut, kemudian kurangnya antisipasi faktor keamanan yang dilakukan oleh personil yang dikarenakan beban laras terlalu berat, sehingga dapat menghambat jalannya perawatan senjata.

Menyikapi permasalahan di atas maka timbul pemikiran pembuatan kontruksi meja pelepas laras meriam $57 \mathrm{~mm}$ AA yang di pergunakan pada saat perawatan dan pemeliharaan laras meriam. Karena pada saat pemeliharaan meriam harus dilaksanakan pembongkaran seluruh komponen penembakan, termasuk pembongkaran laras yang dilaksanakan tim pemeliharaan di satuan Arhanud (Artileri Pertahanan Udara). Dengan adanya meja kerja pelepas laras meriam 57mm AA, tentunya pekerjaan dapat diselesaikan dengan waktu yang relatif lebih cepat dan tidak membutuhkan personil yang banyak. 
Akan tetapi meja maintenance yang sudah dibuat terdapat permasalahan pada sistem hidrolik karena masih belum terukur secara akurat beban kerja dan kemampuan komponen hidroliknya. Untuk itu perlu dilakukan analisis terhadap sistem hidrolik pada meja maintenance laras meriam $57 \mathrm{~mm}$ AA untuk mengurangi kemungkinan terjadinya kendala dan kecelakaan pada saat melakukan perawatan laras meriam $57 \mathrm{~mm}$ AA. Adapun tujuan menganalisis sistem hidrolik meja maintenace ini yaitu untuk meningkatkan efisiensi waktu dan meningkatkan faktor keamanan personil dalam melaksanakan perawatan, pembongkaran, dan pemasangan laras meriam 57mm AA. Berdasarkan uraian di atas, maka diaplikasikan dalam bentuk penelitian dengan judul "Analisa Performa Sistem Hidrolik Meja Maintenance Laras Meriam 57mm AA".

\section{METODOLOGI}

Metode yang digunakan dalam penelitian ini adalah metode analisis yang bertujuan untuk menganalisa performa hidrolik meja maintenance laras meriam $57 \mathrm{~mm}$ AA yang meliputi beberapa komponen diantaranya yaitu, motor listrik, pompa hidrolik, katup selonoid dan reservoir yang terdapat pada sistem hidrolik meja maintenace. Berdasarkan hasil analisa terhadap rangkaian sistem hidrolik yang dilaksanakan dapat dijadikan acuan untuk mengetahui kemampuan sistem hidrolik untuk menggerakan rangkaian meja maintenace. Berikut adalah diagram alir penelitian ini:

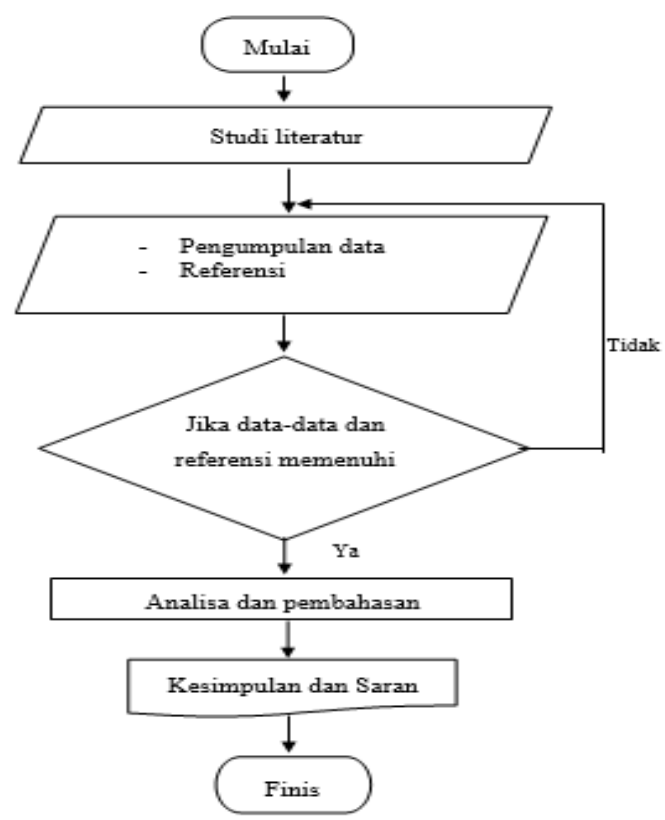

Gambar 1. Diagram Alir Penelitian

\section{Tempat dan Waktu Penelitian}

1. Tempat penelitian. Penelitian alat dilaksanakan di bengkel otomotif Poltekad Kodiklat TNI-AD.

2. Waktu Pelaksanaan. Pelaksanaan penelitian ini dimulai dari Februari s/d Juni 2018.

\section{Variabel Penelitian}

Parameter yang digunakan dalam penelitian ini adalah titik berat keseluruhan pada laras meriam.

- Variabel bebas :

Untuk mendukung kelancaran dalam penelitian yang berjudul analisa performa hidrolik meja maintenance, maka perlu adanya variabel bebas yang ditentukan, adapun variabel yang ditentukan tersebut adalah :

1. Berat laras meriam.

2. Kecepatan langkah piston. 
- Variabel terikat :

Untuk mempermudah dalam melanjutkan penelitian tugas akhir ini maka perlu adanya variabel terikat yang yang diuraikan dari variabel bebas.

Adapun variabel terikat pada penulisan ini meliputi :

1. Daya motor listrik $(\mathrm{kW})$

2. Daya pompa hidrolik $(\mathrm{kW})$

3. Torsi transmisi (Nmm).

\section{Sirkuit Hidrolik Meja Maintenance yang} Digunakan.

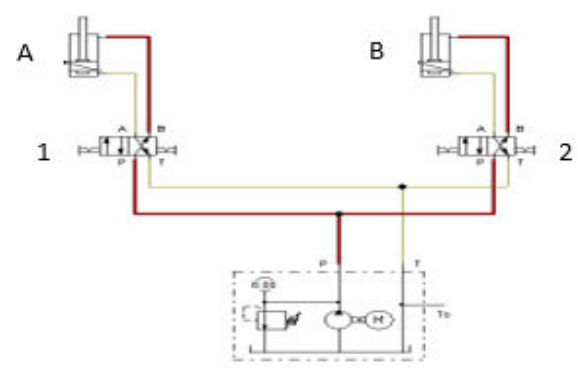

Gambar 2. Rangkaian Sirkuit Hidrolik Meja Maintenance Laras Meriam

Pada gambar sirkuit diatas menunjukan rangkaian sistem hidrolik pada meja maintenance sebelum dioperasikan. Kedua rangkaian silinder hidrolik tidak bergerak dan tidak mendorong kaki meja dikarenakan belum mendapatkan tekanan fluida dari pompa. Cara kerja sistem hidrolik meja maintenance di atas adalah sebagai berikut.

Laras Meriam 57mm. Pada saat motor listrik hidup menggerakkan pompa hidrolik sehingga fluida dari reservoir melalui filter kemudian fluida akan ditekan oleh pompa. Kemudian melewati katup satu arah dialirkan menuju katup kontrol:

a. Katup kontrol 1 digerakkan keatas, fluida bertekanan akan diarahkan menuju ruang silinder 1 bagian bawah. Sehingga batang piston A akan bergerak mendorong keatasmengangkat gandar mekanik 1 dan 2 pada meja, kemudian disesuaikan dengan tinggi laras pada meriamkemudian buka pengunci pada pencekam laras meriam sesuaikan pada laras.

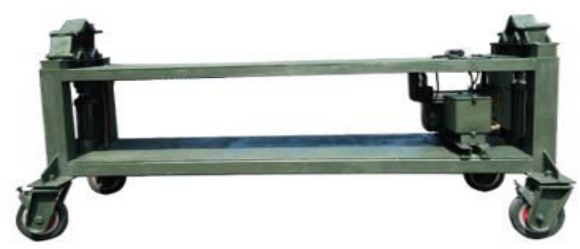

Gambar 3. Meja Maintenance Laras

Meriam Posisi Awal (Sumber: Bengkel

Poltekad)

b. Katup kontrol 2 digerakkan keatas, fluida bertekanan akan diarahkan menuju ruang silinder 2 bagian bawah. Sehingga batang piston akan bergerak mendorong gandar 3 dan 4 keatas disesuaikan dengan tinggi laras pada meriam kemudian buka pengunci pada pencekam laras meriam sesuaikan pada laras.

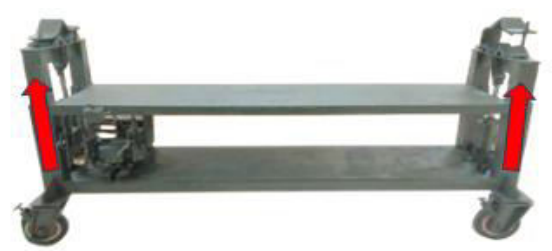

Gambar 4. Meja Maintenance Laras

Meriam Posisi Naik (Sumber: Bengkel

Poltekad)

Setelah tinggi meja sudah sesuai dan pengunci laras sudah dikunci maka tindakan selanjutnya yaitu katup kontrol 1 dan 2 digerakkan kebawah, fluida bertekanan akan diarahkan menuju ruang silinder bagian atas. Sehingga batang piston akan bergerak menarik gandar mekanik sesuai yang diinginkan. Pada saat ini fluida yang berada 
diruang silinder terdorong dan fluida mengalir kembali ke reservoir. Setelah piston mencapai dorongan maksimum, maka katup kontrol digerakkan kembali ke posisi netral.

Setelah laras meriam $57 \mathrm{~mm}$ selesai dilaksanakan pemeliharaan maka tindakan selanjutnya yaitu :

a. Katup kontrol 1 dan 2 digerakkan keatas, fluida bertekanan akan diarahkan menuju ruang silinder 1 bagian bawah. Sehingga batang piston A akan bergerak mendorong keatas mengangkat gandar mekanik pada meja, kemudian disesuaikan dengan tinggi laras pada meriam kemudian buka pengunci pada pencekam laras meriam sesuaikan pada laras.

b. Dorong meja kearah rumah pegas pengembali pada laras meriam $57 \mathrm{~mm}$ sesuaikan kelubang pada belakang laras sampai ujung laras masuk pada rumah pegas pengembali kemudian dorong laras hingga sesuai pada rumah pegas pengembali.

\section{PEMBAHASAN}

1. Umum

Dalam merencanakan sistem hidrolik dilakukan perhitungan-perhitungan yang didukung oleh teori-teori yang sesuai, sehingga ditemukan suatu hasil yang memenuhi syarat sesuai dengan beban kerja yang direncanakan, dan alat bisa bekerja sesuai dengan fungsinya. Untuk penggunaan komponen-komponen hidrolik ini disesuaikan dengan yang ada dipasaran.

2. Sistem Hidrolik
Hidrolik adalah suatu pemanfaatan fluida untuk memindahkan tenaga dari satu titik ke titik yang lainnya. Pada sistem hidrolik fluida akan meneruskan tekanan yang berasal dari pompa hidrolik ke piston yang ada pada silinder hidrolik, dimana piston tersebut dihubungkan dengan suatu batang piston

3. Gaya yang Bekerja pada Sistem Hidrolik

Data spesifikasi laras meriam adalah sebagai berikut:

Berat laras meriam $57 \mathrm{~mm}=330 \mathrm{~kg}$ x 9,81 $\mathrm{m} / \mathrm{s}^{2}=3237,3 \mathrm{~N}$

Berat bagian atas meja kerja $=100 \mathrm{~kg} \times 9,81$ $\mathrm{m} / \mathrm{s}^{2}=981 \mathrm{~N}$

Berat total $=430 \mathrm{~kg} \times 9,81 \mathrm{~m} / \mathrm{s}^{2}=4218,3 \mathrm{~N}$

Dengan beban yang direncanakan pada penyangga belakang $300 \mathrm{~kg}$, pada penyangga depan $130 \mathrm{~kg}$. Dengan demikian besarnya gaya yang diterima silinder hidrolik belakang $300 \mathrm{~kg} \times 9,81 \mathrm{~m} / \mathrm{s}^{2}=2943 \mathrm{~N}$ dan gaya yang

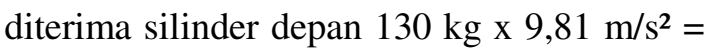
$1275,3 \mathrm{~N}$.

Berdasarkan Hukum Pascal, jika sebuah gaya (F) bekerja pada fluida tertutup melalui suatu penampang permukaan (A), maka akan terjadi tekanan (p) pada fluida.

$$
P=\frac{F}{A}\left(\mathrm{~N} / \mathrm{mm}^{2}\right)
$$

Dimana :

$$
\begin{array}{rll}
\mathrm{p} & : & \text { Tekanan }\left(\mathrm{N} / \mathrm{mm}^{2}\right) \\
\mathrm{F} & : & \text { Gaya }(\mathrm{N}) \\
\mathrm{A} & : & \text { Luas penampang } \\
\left(\mathrm{mm}^{2}\right) & &
\end{array}
$$


Pada silinder 1 memiliki beban 2943 $\mathrm{N}$ dan diameter silinder $50 \mathrm{~mm}$ efisensi hidrolik 0,90.

$$
\begin{aligned}
& \mathrm{P}=\frac{\mathrm{F}_{1} / \eta \mathrm{h}}{\mathrm{A}_{1}} \\
& \mathrm{P}=1,666 \frac{\mathrm{N}}{\mathrm{mm}^{2}}
\end{aligned}
$$

Dicari luas penampang dan diameter silinder 2 yaitu :

$$
\mathrm{A}_{2}=\frac{\mathrm{F}_{2}}{\mathrm{P}}
$$

Dimana :

$$
\begin{gathered}
\mathrm{P}: \text { Tekanan }\left(\mathrm{N} / \mathrm{mm}^{2}\right) \\
\mathrm{F}: \text { Gaya }(\mathrm{N}) \\
\mathrm{A}: \text { Luas penampang }\left(\mathrm{mm}^{2}\right) \\
\mathrm{A}_{2}=\frac{\mathrm{F}_{2}}{\mathrm{P}} \\
\mathrm{A}_{2}=765,38 \mathrm{~mm}^{2}
\end{gathered}
$$

Diameter silinder 2 dengan hasil perhitungan:

$$
\mathrm{A}=\frac{\pi}{4} \mathrm{~d}^{2}
$$

Dimana:

$$
\begin{aligned}
& \text { A : Luas Penampang } \\
& \text { D : Diameter silinder }
\end{aligned}
$$

$$
\begin{aligned}
& d^{2}=\frac{\text { A. } .4}{\pi} \\
& d=31,22 \mathrm{~mm}
\end{aligned}
$$

Silinder 2 yang digunakan dengan diameter $40 \mathrm{~mm}$. Karena tekanan yang dibutuhkan silinder satu $1,666 \mathrm{~N} / \mathrm{mm}^{2}$ maka tekanan kerja sistem hidrolik disesuikan besarnya tekanan silinder satu dan dua.

4. Tebal Tabung Silinder
Silinder hidrolik yang digunakan pada perencanaan sistem hidrolik ini adalah jenis silinder kerja ganda. Silinder kerja ganda menggunakan penyaluran fluida melalui kedua posisi piston. Sebelum menentukan ukuran silinder hidrolik harus diketahui terlebih dahulu besarnya gaya yang harus dilawan atau diterima. Besarnya gaya yang diterima dan jarak yang dilalui adalah faktor yang sangat menentukan dalam pemilihan silinder. Silinder hidrolik direncanakan terbuat dari baja karbon cor SC 49 dengan batas mulur $25 \mathrm{~kg} / \mathrm{mm}^{2}=245,25\left(\mathrm{~N} / \mathrm{mm}^{2}\right)$. Dengan faktor keamanan yang dipakai 2 jika bahan akan terjadi beban lentur.

Tebal tabung silinder. Tebal tabung silinder sebagai berikut:

$$
\mathrm{t}=\frac{\mathrm{Ds}}{2}\left[\sqrt{\frac{\mathrm{sd}+\mathrm{p}}{\mathrm{sd}-\mathrm{p}}-1}\right] \mathrm{mm}
$$

Dimana:

$\mathrm{t}_{\mathrm{s}} \quad: \quad$ Tebal tabung silinder $(\mathrm{mm})$

$\mathrm{D}_{\mathrm{s}} \quad$ : Diameter silinder dalam (mm)

$\mathrm{S}_{\mathrm{d}} \quad$ : $\quad$ Tegangan kerja yang diijinkan $\left(\mathrm{N} / \mathrm{mm}^{2}\right)$.

$$
\mathrm{S}_{\mathrm{d}}=\frac{\mathrm{S}}{\mathrm{K}}
$$

$$
\begin{array}{lll}
\mathrm{S} & : & \text { Batas mulur }\left(\mathrm{Kg} / \mathrm{mm}^{2}\right) \\
\mathrm{K} & : & \text { Faktor keamanan }(1,5-2) \\
\mathrm{P} & : & \text { Tekanan kerja }\left(\mathrm{Kg} / \mathrm{mm}^{2}\right)
\end{array}
$$

(Sumber : Drs Sugi Hartono,309)

Dimana dapat dihitung sebagai berikut :

$$
\begin{aligned}
& S_{d}=\frac{S}{K}\left(\mathrm{~N} / \mathrm{mm}^{2}\right) \\
& S_{d}=112,815\left(\mathrm{~N} / \mathrm{mm}^{2}\right)
\end{aligned}
$$


Maka :

$$
\mathrm{t}_{\mathrm{s}}=\frac{25 \mathrm{~mm}}{2} \cdot\left[\sqrt{\frac{112,815\left(\mathrm{~N} / \mathrm{mm}^{2}\right)+1,66624204\left(\mathrm{~N} / \mathrm{mm}^{2}\right)}{112,815\left(\mathrm{~N} / \mathrm{mm}^{2}\right)-1,66624204\left(\mathrm{~N} / \mathrm{mm}^{2}\right)}}-1\right]
$$

$\mathrm{t}_{\mathrm{s}}=2,074 \mathrm{~mm}$

(Dipasaran hanya tersedia silinder dengan tebal 2-4 $\mathrm{mm}$, sehingga dipilih dengan tebal $3 \mathrm{~mm}$ ).

5. Diameter Luar pada Silinder Hidrolik

$$
\mathrm{DI}=\mathrm{D}_{\mathrm{S}}+2 \cdot \mathrm{t}_{\mathrm{S}}(\mathrm{mm})
$$

Dimana:

$$
\begin{aligned}
\mathrm{D}_{\mathrm{S}} & =\text { Diameter silinder } \\
\mathrm{t}_{\mathrm{S}}(\mathrm{mm}) & =\text { Tebal silinder } \\
\text { DI } & =\mathrm{D}_{\mathrm{S}}+2 . \mathrm{t}_{\mathrm{S}}(\mathrm{mm}) \\
& =50(\mathrm{~mm})+(2.3 \mathrm{~mm}) \\
\text { DI } & =56 \mathrm{~mm}
\end{aligned}
$$

Direncanakan panjang langkah silinder kerja pada meja maintenance laras meriam $250 \mathrm{~mm}$, sehingga :

$$
\mathrm{V}_{\mathrm{S}}=\mathrm{A}_{\mathrm{S}} \cdot \mathrm{S}
$$

Dimana:

$\mathrm{V}_{\mathrm{S}}:$ Volume silinder

$\mathrm{A}_{\mathrm{S}}$ : Luas penampang silinder

S : Panjang langkah silinder

$$
\begin{aligned}
\mathrm{V}_{\mathrm{S}} & =\mathrm{A}_{\mathrm{S}} \cdot \mathrm{S} \\
\mathrm{V}_{\mathrm{S}} & =\frac{1}{4} \cdot 3,14 \cdot(50 \mathrm{~mm})^{2} \cdot 250(\mathrm{~mm}) \\
& =490625 \mathrm{~mm}^{3} \\
\mathrm{~V}_{\mathrm{S}} & =0,490(\text { Liter })
\end{aligned}
$$

Volume piston. Direncanakan tebal piston $30 \mathrm{~mm}$, maka:
$\mathrm{V}_{\mathrm{p}}$ : Volume piston

$A_{p}:$ Luas penampang silinder

$\mathrm{S}$ : Tebal piston

$$
\begin{aligned}
\mathrm{V}_{\mathrm{p}} & =\frac{1}{4} \cdot 3,14 \cdot(50 \mathrm{~mm})^{2} \cdot 30(\mathrm{~mm}) \\
& =58875\left(\mathrm{~mm}^{3}\right) \\
\mathrm{v}_{\mathrm{p}} & =0,058(\text { Liter })
\end{aligned}
$$

Maka besarnya volume tekan maksimal

$$
\begin{aligned}
\mathrm{V}_{\mathrm{T}} & =490625 \mathrm{~mm}^{3}-58875 \mathrm{~mm}^{3} \\
& =437150 \mathrm{~mm}^{3} \\
\mathrm{~V}_{\mathrm{T}} & =0,431 \text { Liter }
\end{aligned}
$$

Volume silinder angkat $\left(\mathrm{V}_{\mathrm{A}}\right)$. Volume tangkai piston. Direncanakan diameter tangkai piston $30 \mathrm{~mm}$, maka :

$$
\mathrm{V}_{\mathrm{TP}}=\mathrm{A}_{\mathrm{TP}} \cdot \mathrm{S}_{\mathrm{TP}} \text { (Liter) }
$$

Dimana:

$$
\begin{array}{ll}
\mathrm{V}_{\mathrm{TP}} & : \text { Volume silinder angkat } \\
\mathrm{A}_{\mathrm{TP}} & : \text { Luas penampang piston } \\
\mathrm{S}_{\mathrm{TP}} & : \text { Panjang langkah }
\end{array}
$$

$$
\begin{aligned}
\mathrm{V}_{\mathrm{TP}} & =\mathrm{A}_{\mathrm{TP}} \cdot \mathrm{S}_{\mathrm{TP}} \text { (Liter) } \\
\mathrm{V}_{\mathrm{TP}} & =\frac{1}{4} \cdot 3,14 \cdot(30 \mathrm{~mm})^{2} \cdot 250(\mathrm{~mm}) \\
& =155430\left(\mathrm{~mm}^{3}\right) \\
\mathrm{V}_{\mathrm{TP}} & =0,155(\text { Liter })
\end{aligned}
$$

Maka besarnya volume angkat maksimal:

$$
\begin{aligned}
\mathrm{V}_{\mathrm{A}} & =\mathrm{V}_{\mathrm{T}}-\mathrm{V}_{\mathrm{TP}}(\text { Liter }) \\
\mathrm{V}_{\mathrm{A}} & =431750 \mathrm{~mm}^{2}-155430 \mathrm{~mm}^{2} \\
\mathrm{~V}_{\mathrm{A}} & =276320 \mathrm{~mm}^{3} \\
\mathrm{~V}_{\mathrm{A}} & =0,276 \mathrm{Liter}
\end{aligned}
$$

Kecepatan langkah. Direncanakan satu gerakan pada posisi sejajar dengan laras 6 detik, maka: 


$$
\mathrm{v} \quad=\quad \frac{\mathrm{h}}{\mathrm{t} .1000}(\mathrm{~m} / \mathrm{det})
$$

Dimana :

$$
\begin{array}{lll} 
& \mathrm{v} & : \text { Kecepatan langkah } \\
\mathrm{h} & : \text { Panjang langkah } \\
\mathrm{t} & : \text { waktu } \\
\mathrm{v} & = & \frac{\mathrm{h}}{\mathrm{t} .1000}(\mathrm{~m} / \mathrm{det}) \\
\mathrm{v} & =\frac{250 \mathrm{~mm}}{6.1000} \\
\mathrm{v} & = & 0,041 \mathrm{~m} / \mathrm{det}
\end{array}
$$

Debit fluida saat mengangkat beban.

$$
\begin{aligned}
\mathrm{Q}_{\mathrm{A}} & =\frac{\mathrm{V}_{\mathrm{T}}(\mathrm{L})}{\mathrm{t}(\mathrm{det})}(1 / \text { menit }) \\
& =\frac{0,437150(\mathrm{~L})}{6(\mathrm{det})} \cdot 60 \\
\mathrm{Q}_{\mathrm{A}} & =4,317 \mathrm{l} / \text { menit }
\end{aligned}
$$

Debit fluida saat turun.

$$
\begin{aligned}
\mathrm{Q}_{\mathrm{T}} & =\frac{\mathrm{V}_{\mathrm{A}}(\mathrm{L})}{\mathrm{t}(\mathrm{det})}(1 / \text { menit }) \\
& =\frac{0,2763(\mathrm{~L})}{6(\mathrm{det})} .60 \\
\mathrm{Q}_{\mathrm{T}} & =2,7631 / \text { menit }
\end{aligned}
$$

Setelah melaksanakan perhitungan pada silinder kerja sesuai dengan perencanaan beban, maka perlu dipilih pompa hidrolik yang mampu melayani silinder kerja. Putaran pompa direncanakan $1500 \mathrm{rpm}$. Sehingga perlu diketahui debit dan daya pompa hidrolik yang sesuai.

6. Pemilihan Pipa Penyalur

Tabel 1. Spesifikasi Pipa Penyalur (Sumber: Sugi Hartono, 1988)

\begin{tabular}{|c|c|c|c|c|c|}
\hline $\begin{array}{c}\text { Diameter } \\
\text { Luar } \\
(\mathbf{m m})\end{array}$ & $\begin{array}{c}\text { Tebal } \\
\text { dinding } \\
\text { pipa } \\
(\mathrm{mm})\end{array}$ & $\begin{array}{c}\text { Tekanan } \\
\text { Maksimal } \\
\text { Terhitung } \\
\text { (bar) }\end{array}$ & $\begin{array}{c}\text { Diameter } \\
\text { luar } \\
(\mathrm{mm})\end{array}$ & $\begin{array}{c}\text { Tebal } \\
\text { dinding } \\
\text { pipa } \\
(\mathrm{mm})\end{array}$ & $\begin{array}{c}\text { Tekanan } \\
\text { Maksimal } \\
\text { Terhitung } \\
\text { (bar) }\end{array}$ \\
\hline 4 & 1 & 600 & 18 & 3 & 365 \\
\hline 5 & 1 & 400 & 20 & 2 & 193 \\
\hline 6 & 1 & 300 & 20 & 3 & 313 \\
\hline 6 & 2 & 1200 & 22 & 01.05 & 122 \\
\hline 8 & 1 & 228 & 22 & 3 & 273 \\
\hline 8 & 2 & 686 & 25 & 2 & 147 \\
\hline 10 & 1 & 172 & 25 & 3 & 230 \\
\hline 10 & 2 & 458 & 28 & 01.05 & 92 \\
\hline 12 & 1 & 137 & 28 & 3 & 199 \\
\hline 12 & 2 & 343 & 30 & 2,5 & 119 \\
\hline 14 & 1 & 128 & 30 & 4 & 265 \\
\hline 14 & 2 & 309 & 35 & 2 & 100 \\
\hline 15 & 01.05 & 192 & 35 & 4 & 216 \\
\hline 15 & 2,5 & 365 & 38 & 3 & 136 \\
\hline 16 & 01.05 & 177 & 38 & 5 & 261 \\
\hline 16 & 2,5 & 331 & 42 & 2 & 81 \\
\hline 18 & 01.05 & 154 & & & \\
\hline & & & & & \\
\hline
\end{tabular}

\section{Pompa}

Jenis pompa, debit aliran fluida yang dibutuhkan oleh silinder sebesar 10,935 liter/menit type pompa yang digunakan sebagai berikut :

$$
\begin{aligned}
\mathrm{V}_{\mathrm{P}} & =\frac{\mathrm{Q}_{\mathrm{sil}} \cdot 1000}{1500(\mathrm{rpm}) \cdot \eta_{\mathrm{vol}}}(\mathrm{cc} / \mathrm{rev}) \\
\mathrm{V}_{\mathrm{P}} & =\frac{10,935(\mathrm{~L} / \mathrm{menit}) \cdot 1000}{1500(\mathrm{rpm}) \cdot 0,9}(\mathrm{cc} / \mathrm{rev}) \\
\mathrm{V}_{\mathrm{P}} & =8,1(\mathrm{cc} / \mathrm{rev})
\end{aligned}
$$

Volume pompa yang dibutuhkan 8,1 cc/rev dipilih pompa roda gigi (gear) model HGP-2A-F11R yang memiliki kemampuan 205,95 bar dan 10,5 cc/rev.

\section{Kopling}

Penghubung atau penerus putaran yang akan meneruskan putaran dari motor penggerak ke poros pompa menggunakan jenis kopling fleksibel dengan tipe NM-67 bekerja pada daya $1 \mathrm{HP}$.

9. Daya Motor Listrik

Daya kerja motor listrik dapat dihitung dengan persamaan berikut ini : 


$$
\begin{aligned}
& \mathrm{N}=\frac{(1+\alpha) \mathrm{P}_{\mathrm{pm}}}{\eta}(\mathrm{kw}) \\
& \mathrm{N}=\frac{(1+0,2) 9,24}{0,95}(\mathrm{kw}) \\
& \text { Nmotor }=11,67 \mathrm{kw}
\end{aligned}
$$

Jadidaya motor listrik yang dibutuhkanmempunyaidaya11,67kW,dipasar antersediadaya motor listrikdengandaya 3/4 PK.

\section{Buckling/Bengkokan}

Suatu poros akan mengalami bengkokan apabila dikenakan gaya yang arahnya searah dengan poros tersebut. Poros harus memiliki diameter yang mencukupi untuk mengangkat beban tersebut, sehingga akan menghindari terjadinya buckling/bengkokan pada silinder.

Tekanan yang diterima oleh batang piston serta adanya pengaruh yang diakibatkan oleh gesekan maka tekanan kerja dikalikan dengan faktor kerja (a) yang besarnya 1,2-1,5, berkisar antara besaran tekanan pada batang piston sebagai berikut:

$$
\begin{aligned}
& \mathrm{P}=1,6662\left(\mathrm{~N} / \mathrm{mm}^{2}\right) \cdot 1,5=2,4999 \\
& \left(\mathrm{~N} / \mathrm{mm}^{2}\right)=24,99(\mathrm{Bar})
\end{aligned}
$$

Tekanan kerja dari sistem hidrolik sebesar 1,6662(N/mm²) maka diplilihlah bahan SC37 dimana memiliki tegangan tarik $37 \mathrm{~kg} / \mathrm{mm}^{2}$.

Direncanakan panjang tangkai piston 150 $\mathrm{mm}$ dan diameter batang piston $15 \mathrm{~mm}$, besarnya moment inersia:

$$
\begin{aligned}
& I=\frac{\pi d^{4}}{64} \\
& I=\frac{3,14 \times 15^{4} \mathrm{~mm}}{64} \\
& I=24,8379.10^{-9} \mathrm{~mm}^{4}
\end{aligned}
$$

Berdasarkan rancangan yang digunakan adalah menggunakan baja maka dapat diketahui bahwa modulus elastisitas baja adalah $\left(220 \times 10^{9} \mathrm{~N} / \mathrm{m}^{2}\right)$.

Sehingga:

$$
\mathrm{K}=\frac{\pi^{2} \cdot \mathrm{E} \cdot \mathrm{I}}{\mathrm{L}_{\mathrm{k}}^{2}}
$$

Dimana:

$$
\begin{aligned}
\mathrm{K} & =\text { Gaya buckling }(\mathrm{N}) \\
\mathrm{E} & =\text { Modulus elastisitas }\left(\mathrm{N} / \mathrm{mm}^{2}\right) \\
\mathrm{I} & =\text { Moment inersia batang piston } \\
\left(\mathrm{mm}^{4}\right) & \\
\mathrm{L}_{\mathrm{k}} & =\text { Panjang ekivalen silinder }(\mathrm{m})
\end{aligned}
$$

(Elemen mesin, Hirt.Dr.Ing.M,hal 60)

$$
\begin{aligned}
\mathrm{K} & =\frac{\pi^{2} \cdot \mathrm{E} \cdot \mathrm{I}}{\mathrm{L}_{\mathrm{k}}{ }^{2}} \\
\mathrm{~K} & =\frac{3,14^{2} \cdot 220 \cdot 10^{9} \mathrm{~N} / \mathrm{m}^{2} \cdot 24,8 \cdot 10^{-9} \mathrm{~mm}^{4}}{150^{2} \mathrm{~mm}} \\
\mathrm{~K} & =2,39 \cdot 10^{6} \mathrm{~N}
\end{aligned}
$$

Besarnya gaya tekan yang diijinkan :

$$
\mathrm{F}=\frac{\mathrm{K}}{\mathrm{S}}(\mathrm{N})
$$

Dimana :

$\mathrm{F} \quad=$ Gaya tekan yang diijinkan $(\mathrm{N})$

$\mathrm{K}$ =Gaya buckling $(\mathrm{N})$

$\mathrm{S} \quad=$ Faktor keamanan $(2,5-3,5)$

(Elemen mesin, Hirt.Dr.Ing.M,hal 60)

$$
\begin{aligned}
& F=\frac{K}{S}(N) \\
& F=\frac{2,39 \cdot 10^{6} \mathrm{~N}}{3,5} \\
& F=6,8 \cdot 10^{6} \mathrm{~N}
\end{aligned}
$$

Jadi poros yang direncanakan tidak mengalami bengkok karena besarnya gaya 
tekan diijinkan lebih besar dari gaya tekan sebenarnya yaitu

$$
6,8 \cdot 10^{6}(\mathrm{~N})>2,39 \cdot 10^{6}(\mathrm{~N}) \text {. }
$$

\section{Bushing}

Bushing merupakan pengaman dari silinder hidrolik yang berfungsi untuk menahan gerakan piston dan batang piston dari goncangan ketika sistem hidrolik sedang bekerja.Bahan yang dipakai untuk baut adalah jenis baja karbon S30C difinis biasa dengan kandungan karbon 30\% sehingga $\sigma_{\mathrm{a}}=$ $4,8 \mathrm{Kg} / \mathrm{mm}^{2}$.

Perhitungan diameter baut $(\mathrm{d}) \mathrm{W}=300 \mathrm{~kg}$ dibagi dengan jumlah baut (4buah) $\frac{300}{4}=75$ $\mathrm{kg}$.

$$
\sigma_{\mathrm{t}}=\frac{\mathrm{W}}{\mathrm{A}}=\frac{\mathrm{W}}{\left(\frac{\pi}{4}\right) \cdot \mathrm{d}_{1}^{4}}\left(\mathrm{~kg} / \mathrm{mm}^{2}\right)
$$

Dimana:

$\mathrm{W}=$ Beban tarik aksial pada baut $(\mathrm{kg})$.

$\sigma_{\mathrm{t}}=$ Tegangan tarik $\left(\mathrm{kg} / \mathrm{mm}^{2}\right)$.

(Sumber : Sularso, 1997 hal 296 )

Sehingga:

$$
\begin{aligned}
\mathrm{d} & \geq \sqrt{\frac{4 \cdot \mathrm{W}}{\pi \cdot \sigma_{\mathrm{a}} \times 0,64}} \\
\mathrm{~d} & =\sqrt{31,12 \mathrm{~mm}^{2}} \\
& 5,57
\end{aligned}
$$

Jadi diameter baut yang mampu untuk menahan beban yang terjadi pada silinder hidrolik sebesar $5,57 \mathrm{~mm}$.

Penghubung atau penerus putaran yang akan meneruskan putaran dari motor penggerak ke poros pompa menggunakan jenis kopling fleksibel dengan tipe NM-67 bekerja pada daya $1 \mathrm{HP}$.

\section{Reservoir}

Perhitungan

dalam menentukanreservoir dapat dilakukan dengan dengan cara mengalikan 3 sampai 5 sirkulasi fluida dalam sistem hidrolik. Sirkulasi fluida pada sistem ini meliputi volume fluida pada silinder hidrolik, pipa dan pompa. Diketahui volume silinder hidrolik sebesar 490,625 $\mathrm{cm}^{3}$ dan volume pompa sebesar $11,961 \mathrm{~cm}^{3}$. Panjang pipa pada sirkulasi $3500 \mathrm{~mm} \mathrm{(3,5}$ m), volume pada pipa dapat dihitung menggunakan rumus sebagai berikut:

a. Volume Pipa Hidrolik untuk angkat silinder hidrolik $\left(\mathrm{V}_{\mathrm{p}}\right)$.

$$
\begin{aligned}
\mathrm{V}_{\mathrm{p}} & =\frac{1}{4} \cdot \pi \cdot \mathrm{d}_{\mathrm{p}}{ }^{2} \cdot \mathrm{p}_{\mathrm{p}}(\text { liter }) \\
& =\frac{1}{4} \cdot 3,14 \cdot 4(\mathrm{~mm})^{2} \cdot 3500(\mathrm{~mm}) \\
& =10990 \mathrm{~mm}^{3} \\
\mathrm{~V}_{\mathrm{p}} & =1,099 \text { liter }
\end{aligned}
$$

b. Volume Total Sirkulasi $\left(\mathrm{V}_{\mathrm{tot}}\right)$.

$$
\begin{aligned}
\mathrm{v}_{\text {tot }} & =\mathrm{V}_{\mathrm{p}}+2 \cdot \mathrm{V}_{\mathrm{s}}+\mathrm{V}_{\mathrm{pm}} \text { (liter) } \\
& =1,099(\mathrm{~L})+2 \cdot 490,625\left(\mathrm{~cm}^{3}\right)+11,961\left(\mathrm{~cm}^{3}\right) \\
\mathrm{V}_{\text {tot }} & =1,590 \text { liter }
\end{aligned}
$$

Volume Reservoir $\left(\mathrm{V}_{\mathrm{sr}}\right)$.

$$
\begin{aligned}
\mathrm{v}_{\mathrm{sr}} & =5 \cdot \mathrm{v}_{\text {tot }} \text { (liter) } \\
& =5.1,590961 \text { (liter) } \\
\mathrm{V}_{\mathrm{sr}} & =7,95 \text { liter }
\end{aligned}
$$

Sehingga reservoir yang dibuat dengan dimensi :
a. Tinggi : $170 \mathrm{~mm}$
b. Lebar : $180 \mathrm{~mm}$
c. Panjang : $300 \mathrm{~mm}$

Jadi volume reservoir sebagai berikut : 


$$
\begin{array}{rll}
\mathrm{Vr} & = & \text { P.L.T (liter) } \\
& =300 \mathrm{~mm} \cdot 180 \mathrm{~mm} \cdot 170 \mathrm{~mm} \\
\mathrm{Vr} & =9,81 \text { liter }
\end{array}
$$

13. Motor Hidrolik

Berdasarkan pada hasil penghitungan dapat diketahui bahwa besar gaya aksial adalah 4218,3N sehingga besar kerja motor hidrolik dapat dihitung sebagai berikut:

$$
\mathrm{p}_{\mathrm{e}}=\frac{\mathrm{F} / \eta_{\mathrm{h}}}{\mathrm{A}} \text { (bar) }
$$

Dimana :

$\mathrm{p}_{\mathrm{e}} \quad$ : Tekanan kerja motor hidrolik (bar)

$\mathrm{F}_{\mathrm{a}} \quad$ : Gaya aksial $(\mathrm{N})$

$\eta_{\mathrm{h}} \quad$ : Evisiensi motor hidrolik $(0,85-0,95)$

A : Diameter saluran imput dan output (mm)

(Sumber : Drs. Sugi Hartono, 1988)

$$
\begin{aligned}
& P_{e}=\frac{F / \mathrm{\eta}_{h}}{A} \\
= & \frac{4218,3 \mathrm{~N} / 0,95}{\frac{1}{4} \cdot 3,14 \cdot\left(40 \mathrm{~mm}^{2}\right)}
\end{aligned}
$$$$
\mathrm{P}_{\mathrm{S}} \quad=\quad 24,35 \mathrm{bar}
$$

Tekanan kerja maksimal motor hidrolik berdasarkan tabel spesifikasi dari pada motor hidrolik adalah 30 bar, sedangkan tekanan kerja yang dihasilkan oleh motor hidrolik penggerak dalam pengoperasian hanya 24,35 bar, sehinngga dapat disimpulkan bahwa motor hidrolik mampu bekerja dengan baik.

c. Torsi penggerak (M).

$$
\mathrm{M}=\frac{\Delta \mathrm{p} \cdot \mathrm{V} \cdot \eta_{\mathrm{hm}}}{2 \cdot \pi \cdot 100}(\mathrm{Nm})
$$

Dimana:

$\Delta \mathrm{p} \quad$ : penurunan tekanan antara inlet dan outlet (bar)
$\mathrm{V} \quad$ : volume geometrik motor $\left(\mathrm{cm}^{3}\right)$

$\eta_{\mathrm{hm}}$ : Evisiensi hidro mekanik ( 0,9 $0,95)$

$$
\begin{aligned}
& =\frac{7 \cdot 5,0 \cdot 0,9}{2 \cdot 3,14 \cdot 100} \\
& =\frac{31,5}{628} \\
& =0,05 \mathrm{Nm}
\end{aligned}
$$

Torsi maksimal yang dapat hasilkan oleh motor hidrolik berdasarkan spesifikasi daripada motor hidrolik adalah 6,7 Nm, sedangkan torsi yang dihasilkan oleh motor hidrolik dalam rangkaian kerja nya hanya mencapai 1,57 Nm, sehingga dapat disimpulkan bahwa motor hidrolik mampu bekerja dengan baik, karena torsi yang dihasilkan motor hidroik dalam rangkaian kerjanya lebih kecil daripada torsi spesifikasi.

d. Torsi motor hidrolik $\left(\mathrm{P}_{\mathrm{t}}\right)$

$$
T_{t}=\frac{2 \cdot \pi \cdot n \cdot M}{60}
$$

$\mathrm{T}_{\mathrm{t}} \quad$ : Torsi motor hidrolik (Nm)

$\mathrm{n} \quad$ : putaran motor (rpm)

M : Torsi penggerak (Nm)

(Sumber : Drs. Sugi Hartono, 1988)

$$
\begin{aligned}
& \mathrm{T}_{\mathrm{t}}=\frac{2 \cdot \pi \cdot \mathrm{n} \cdot \mathrm{M}}{60} \\
& \mathrm{~T}_{\mathrm{t}}=\frac{2 \cdot 3,14 \cdot 1500 \cdot 0,05}{60} \\
& \mathrm{~T}_{\mathrm{t}}=7,85 \mathrm{Nm}
\end{aligned}
$$

Torsi maksiamal yang dibutuhkan oleh motor hidrolik berdasarkan spesifikasi daripada motor hidrolik adalah 6,7 Nm, sedangkan torsi yang dihasilkan oleh motor 
hidrolik dalam rangkaian kerja nya sebesar 7,85 Nm, sehingga dapat disimpulkan bahwa motor hidrolik mampu bekerja dengan baik, karena torsi yang dihasilkan motor hidroik dalam rangkaian kerjanya lebih besar daripada torsi spesikasi.

e. Daya kerja motor hidrolik (P).

$$
\begin{aligned}
& \mathrm{P}_{\mathrm{m}}=\frac{\Delta \mathrm{p} \cdot \mathrm{Q} \cdot \eta_{\text {tot }}}{600}(\mathrm{~kW}) \\
& P_{m} \quad: \text { Daya Motor hidrolik }(\mathrm{kW}) \\
& \Delta p \quad: \text { Penurunan tekanan antara } \\
& \quad \begin{array}{l}
\text { intlet dan outlet motor (bar) } \\
\mathrm{Q} \quad \text { penekanan (liter/menit) }
\end{array} \\
& \eta_{\text {tot }} \quad \text { : evisiensi total }(0,8-0,85)
\end{aligned}
$$

$$
\begin{aligned}
& \mathrm{P}_{\mathrm{m}}=\frac{\Delta \mathrm{p} \cdot \mathrm{Q} \cdot \eta_{\text {tot }}}{600} \\
& \mathrm{P}_{\mathrm{m}}=\frac{7 \text { (bar) }) .11,524 \text { (liter } / \text { menit) } .0,8}{600} \\
& \mathrm{P}_{\mathrm{m}}=0,11 \mathrm{~kW}
\end{aligned}
$$

Daya maksimal yang dapat hasilkan oleh motor hidrolik elevasiberdasarkan spesifikasi daripada motor hidrolik tersebut adalah $0,4 \mathrm{~kW}$, sedangkan daya kerja yang dicapai oleh motor hidrolik hanya mencapai 0,11 kW, sehingga dapat di simpulkan bahwa motor hidrolik mampu bekerja dengan baik, karena daya kerja motor hidrolik lebih kecil daripada daya spesifikasi.

f. Efisiensi $(\eta)$.

$$
\eta_{\mathrm{h}}=\frac{\mathrm{P}_{\mathrm{se}} \cdot 100}{\mathrm{P}_{\mathrm{te}} \cdot 1} \%
$$

Dimana

$$
\eta_{h} \quad \text { Evisiensi mekanik (\%) }
$$

$$
\begin{aligned}
& T_{\text {se }} \text { : Torsi Sebenarnya (Nm) } \\
& T_{\text {te }} \text { : Torsi Teoritis (Nm) }
\end{aligned}
$$

(Sumber : Sugi Hartono, 1988)

$$
\begin{aligned}
\eta_{h} & =\frac{P_{\text {se }} \cdot 100}{P_{\text {te }} \cdot 1} \% \\
\eta_{h} & =\frac{6,7 \mathrm{Nm} \cdot 100}{7,85 \mathrm{Nm} \cdot 1} \% \\
\eta_{h} & =85 \%
\end{aligned}
$$

\section{SIMPULAN}

Berdasarkan hasil analisis performa hidrolik pada meja maintenance laras meriam $57 \mathrm{~mm}$ dapat diambil kesimpulan sebagai berikut :

a. Pompa yang digunakan adalah model HGP-2A-F11R yang memiliki kemampuan 205,95 bar dan daya maksimal yang dihasilkan oleh pompa hidrolik adalah $0,4 \mathrm{~kW}$, sehingga mampu untuk menyuplai kebutuhan daya kerja yang hanya $0,11 \mathrm{~kW}$. Daya motor listrik yang dibutuhkan untuk pompa hidrolik $3 / 4 \mathrm{PK}=0,56 \mathrm{~kW}$, dengan efisiensi $85 \%$.

b. Tangkai piston yang menggunakan bahan SC37 dengan panjang panjang $150 \mathrm{~mm}$ dan diameter $15 \mathrm{~mm}$. Batang piston tidak akan mengalami bengkokan karena gaya tekan yang diijinkan yaitu lebih besar dari gaya sebenarnya. yang direncanakan tidak mengalami bengkok karena besarnya gaya tekan diijinkan lebih besar dari gaya tekan sebenarnya yaitu 6,8 $106(\mathrm{~N})>2,39$. $106(\mathrm{~N})$.

c. Debit pompa hidrolik sebesar 11,524 1/menit dan tekanan kerja p0mpa hidrolik 
sebesar 24,35 bar, sedangkan untuk torsi maksimal yang dapat hasilkan oleh motor hidrolik berdasarkan spesifikasi daripada pompa hidrolik adalah $6,7 \mathrm{Nm}$, sedangkan torsi yang dihasilkan oleh motor hidrolik dalam rangkaian kerja nya hanya mencapai 1,57 Nm, sehingga dapat disimpulkan bahwa pompa hidrolik mampu bekerja dengan baik, karena torsi yang dihasilkan pompa hidroik dalam rangkaian kerjanya lebih kecil daripada torsi spesifikasi.

\section{DAFTAR PUSTAKA}

Untoro,Joko. 2007.Buku Pintar Fisika. Jakarta: Wahyu Media.

Hartono, Sugi. 1988. Sistim Kontrol dan Pesawat Tenaga Hidrolik.Bandung: Tarsito.

Suga, Kiyokatsu dan Sularso. 1994.Dasar Perencanaan Elemen Mesin. Jakarta: PT. Pradnya Pramita

Popov, EP dan Zainul,Tanisan Astarmar.

1993.Mekanika Teknik, Jakarta: PT Gelora

Aksara. 